\title{
Evaluation of Iranian College Students' Awareness about Infertility Risk Factors
}

\author{
Sanaz Alaee, ${ }^{1}$ Amirreza Talaiekhozani, ${ }^{2,}$, Gholam Reza Ziaei, ${ }^{3}$ and Parvin Lohrasbi ${ }^{4}$ \\ ${ }^{1}$ Department of Reproductive Biology, School of Advanced Medical Sciences and Technologies, Shiraz University of Medical Sciences, Shiraz, IR Iran \\ ${ }^{2}$ Department of Civil Engineering, Jami Institute of Technology, Isfahan, IR Iran \\ ${ }^{3}$ Department of Accounting, Jami Institute of Technology, Isfahan, IR Iran \\ ${ }^{4}$ Department of Biology, School of Science, Shiraz University, Shiraz, IR Iran \\ "Corresponding author: Amirreza Talaiekhozani, Department of Civil Engineering, Jami Institute of Technology, Isfahan, IR Iran. Tel: +98-3152636319, Fax: +98-3152636319, \\ E-mail: atalaie@jami.ac.ir
}

Received 2015 October 29; Revised 2015 December 11; Accepted 2015 December 21.

\begin{abstract}
Background: With technological developments, creation of new industries, and changing human behavior and lifestyles, several new infertility risk factors (IRFs) are discovered annually. Although many studies have been conducted on IRFs, no research has yet been carried out on the awareness of Iranian college students about the many IRFs.

Objectives: Since prevention of infertility in a society is directly related to awareness about infertility, in the present study the awareness of male and female college students about IRFs was evaluated and compared at Jami institute of technology.

Patients and Methods: For this purpose, a survey questionnaire containing 24 factors related to IRFs was developed and 123 college students from Jami institute of technology completed it. All data was extracted from these questionnaires and was statistically analyzed.

Results: The results showed that both male and female participants had moderate awareness (55.86\%) about IRFs. Female participants had significantly more awareness about the effects of cell phone radiation, fast food, and stress in comparison with their male counterparts. However, significantly higher numbers of male participants knew that smoking has negative effects on fertility. Generally, the awareness of females about IRFs was greater than that of males (59.46\% vs. 52.27\%).

Conclusions: College students have a considerable knowledge gap relating to infertility risk factors, which could be due to the lack of a suitable module on IRFs in the curricula of Iranian universities. Generally, females have more awareness than males. The greatest awareness about IRFs concerned smoking, which may result from widespread media coverage.
\end{abstract}

Keywords: Infertility Risk Factors, Awareness, College Students, Gender, Iran

\section{Background}

Given the developments in technology nowadays, each year hundreds of new chemicals are produced and utilized in various industries. Several of these chemicals are released in different ways into the atmosphere, water, and soil, which leads to environmental pollution (1). These pollutants can enter the human body in a variety of ways, resulting in adverse effects on human bodies. Damage to reproductive organs and infertility are among the harmful effects of air and water pollution (2-7). Furthermore, many other infertility risk factors, such as cell phone radiation $(8,9)$, strenuous exercise $(10,11)$, and stress $(12)$ have been identified and evaluated by researchers. All of the abovementioned factors result in increased fertility problems.

Other factors such as excessive use of saunas and Jacuzzis $(13,14)$, increasing body temperature due to fever (15), putting a laptop on the lap, and wearing tight clothing, by increasing scrotum temperature and reducing sperm production, can result in infertility $(16,17)$. Moreover, inactivity and excessive fast food consumption $(18,19)$ leading to obesity can create infertility problems, such as testicular dysfunction and reduced sperm count in males (20-23), and polycystic ovarian syndrome, one of the main causes of infertility in females (24), which most of the time can be treated through lifestyle changes $(25,26)$. Stress, drinking alcoholic beverages, and smoking can each reduce reproductive potential through various mechanisms $(13,14,27-33)$.

Doping, or using anabolic steroids, has the same effect as using androgens or testosterone. These steroids inhibit reproductive hormones, reducing testis size and sperm production, ending in infertility problems (34-36). In females, anabolic hormone use can cause dysmenorrhea, anovulation, and infertility via inhibition of pituitary hormone secretion (37-39).

Findings show that using a cell phone for long periods of time leads to reduction of sperm count and increase of 
abnormal sperm, resulting in infertility $(40,41)$. Other factors leading to adverse effects on both male and female fertility are exposure to intense light (42), microwave oven use (43), working in petrochemical industries $(44,45)$, drinking chlorinated water or swimming in chlorinated swimming pools $(6,46)$, using certain cosmetic products (47), consuming certain medical drugs (48), pesticide exposure (49), food preservatives (50), and prolonged standing (51).

Unawareness of infertility risk factors has a negative effect on fertility and may result in delayed childbearing. Therefore, evaluating people's awareness about these factors is essential for preventing the development of infertility worldwide. Many studies in different countries have been carried out about students' awareness of certain IRFs and have demonstrated that students' knowledge of IRFs is limited (52-58).

Although several studies in Iran have examined infertility, most of them have focused on infertile patients regarding their knowledge about and attitude toward infertility and infertility treatment techniques, while students' awareness about infertility risk factors has not been fully studied.

Since college students in each society are considered to be influential, their awareness about infertility risk factors is a key step in preventing infertility and involuntary childlessness.

\section{Objectives}

In the current study we have evaluated the awareness of college students at Jami institute of technology about different IRFs. Also, since other studies have shown that there may be significant differences between males and females with regard to their knowledge about the causes of infertility $(54,55)$, we also compared the effects of students' gender on their awareness.

\section{Patients and Methods}

\subsection{Questionnaire Design}

Initially, infertility risk factors in males and females were identified by an extensive literature review, and a selfadministered questionnaire was designed. The questionnaire was divided into two main sections: 1 , demographic information, including age, gender, marital status, and level of education; and 2, a list of infertility risk factors that included 24 questions, each with three answer choices, Yes, No, and I don't know. In Box 1, a complete list of infertility risk factors for males and females as used in our questionnaire is presented. It should also be mentioned that the reliability and validity of the questionnaire was checked by use of a pre-sampling of size 15.

\subsection{Participants}

Students of Jami institute of technology, single and married men and women, each with a different level of education, and without considering any other special criteria, were selected as study participants. The participants were selected based on a simple random sampling process. The questionnaires were distributed among the students and filled out by them in May 2015. Participants were assured that their identifying information and responses would be completely confidential. The completed questionnaires were statistically analyzed according to gender.

\subsection{Data Analyses}

The statistical analysis was carried out using SPSS 16 software (SPSS Inc., Chicago, USA). The nonparametric Mann-Whitney U test was performed to compare the means between males and females. Each test with a P less than 0.05 was considered statistically significant (Box 1).

\section{Results}

\subsection{Participants' Demographics}

123 questionnaires were completed during the study by a total of 123 participants. The demographic characteristics of the participants are shown in Table 1.

\subsection{Male and Female Knowledge of Infertility Risk Factors}

Table 2 displays the results of testing the awareness of males and females about infertility risk factors. The results showed that the awareness of females about cell phone radiation, fast food, and stress was significantly higher than that of males. On the other hand, the awareness of males about smoking was significantly higher than of females. There were no significant differences in the awareness of males and females about other infertility risk factors.

\subsection{General Comparison of Students' Awareness About IRFs at} Different Levels of Education

Results showed that the average level of males' awareness of infertility risk factors at Jami institute of technology was generally lower than that of females $(52.27 \%$ vs $59.46 \%$ ) (Table 3).

The female participants studying at the graduate level (MS and $\mathrm{PhD}$ ) correctly answered the questions slightly more often than the undergraduates among them (associate degree and bachelor of science) (62.42\% vs. $56.42 \%)$ 
Box 1. List of Infertility Risk Factors Mentioned in the Questionnaire

\begin{tabular}{|c|c|}
\hline No. & Infertility Risk Factors \\
\hline $\mathbf{1}$ & Temperature \\
\hline 2 & Cell phone radiation \\
\hline 3 & Light intensity \\
\hline 4 & Air pollution \\
\hline 5 & Low-quality drinking water \\
\hline 6 & Fast food \\
\hline 7 & Stress \\
\hline 8 & Strenuous exercise \\
\hline 9 & Microwave oven use \\
\hline 10 & Doping or using anabolic steroids \\
\hline 11 & Working in petrochemical industries \\
\hline 12 & Prolonged standing \\
\hline 13 & Contact with chlorine in swimming pools \\
\hline 14 & Smoking \\
\hline 15 & Drinking alcoholic beverages \\
\hline 16 & Strenuous activities \\
\hline 17 & Cosmetic products \\
\hline 18 & Wearing tight clothes \\
\hline 19 & Excess chlorine in drinking water \\
\hline 20 & Telecommunication towers \\
\hline 21 & Excessive use of laptops \\
\hline 22 & Pesticides \\
\hline 23 & Food preservatives \\
\hline 24 & Some medical drugs \\
\hline
\end{tabular}

Table 1. Participants' Demographics

\begin{tabular}{|c|c|c|}
\hline Parameter & Males & Females \\
\hline Age range, $Y$ & $23.79(1.93)$ & $23.31(1.95)$ \\
\hline \multicolumn{3}{|c|}{ Marital status, No. } \\
\hline Single & 38 & 37 \\
\hline Couples & 23 & 25 \\
\hline Total & 61 & 62 \\
\hline
\end{tabular}

${ }^{\mathrm{a}}$ Values are expressed as mean (SD) unless otherwise indicated.

(Table 3). But in males the awareness of undergraduate students was more than that of graduate students (55.14\% vs. $49.40 \%$ ). But the overall awareness of male and female+ undergraduate and graduate students was similar (55.78\% vs. 55.95\%).
4.4. General Comparison of Students' Awareness About Infertility Risk Factors

According to Table 3, the general awareness of college students was 55.86\%. As shown in Figure 1, the most recognized infertility risk factor among these students was smoking.

\section{Discussion}

Today, infertility is an increasingly significant issue worldwide. Despite the importance of youth knowledge about prevention of infertility and infertility risk factors, these issues are often neglected.

According to our results, male awareness about the adverse effects of smoking on fertility was significantly greater than female, which may be related to the fact that in Iran males are more closely associated with smoking. In contrast to our study, Rouchou et al. illustrated that the awareness of males and females about the effects of smoking on human fertility is almost equal (56). Moreover, in our study smoking was the most recognized infertility risk factor among these students, which could be the consequence of more information in the media about the deleterious effects of smoking.

The significantly greater awareness of female students about cell phone radiation, fast food, and stress than of males which was observed in our study can be related to females' sensitivity to their fertility, childbearing, and motherhood, and their greater uptake of information from the media. In contrast to our results, in one study it was shown that the awareness of males and females about the effects of radiation on human fertility is equal, also similar proportions of male and female students knew about adverse environmental factors, which is inconsistent with our results (56). Other studies have shown a lack of adequate knowledge about infertility risk factors among college students (52-54) and also significantly higher awareness in females than in males (57). Moreover, Sumera et al. (57) observed that less than half of students are aware of the negative effects of alcohol consumption on fertility, while in our study this was higher (around 60\%). This result could be due to the fact that the majority of people in Iran are Muslim and alcohol consumption is prohibited in Islam.

The low levels of awareness about the other mentioned IRFs may be related to lack of sufficient information given about them in the media, schools, and universities.

Our results also demonstrated that higher educational attainment can slightly increase female awareness of infertility risk factors. Since these students' fields of study are engineering-related, such as chemical engineering, mechanical engineering, and civil engineering, there is no 
Table 2. Comparison of Male and Female College Students' Awareness About Infertility Risk Factors by Using Mann-Whitney U test

\begin{tabular}{|c|c|c|c|c|}
\hline Infertility Risk Factor & Mean Rank of Females & Mean Rank of Males & Mann-Whitney U-test & $\mathbf{P}<$ \\
\hline Temperature & 75.41 & 60.79 & 1600.5 & 0.561 \\
\hline Cell phone radiation & $67.77^{\mathrm{a}}$ & 57.23 & 1595 & 0.019 \\
\hline Light intensity & 63.35 & 62.66 & 1931.5 & 0.809 \\
\hline Air pollution & 62.81 & 62.19 & 1902.5 & 0.892 \\
\hline Low quality of drinking water & 61.26 & 63.74 & 1845 & 0.667 \\
\hline Fast food & $69.65^{\mathrm{a}}$ & 55.35 & 1479 & 0.007 \\
\hline Stress & $69.92^{\mathrm{a}}$ & 55.08 & 1462 & 0.004 \\
\hline Strenuous exercise & 64.78 & 61.19 & 1841 & 0.536 \\
\hline Microwaves & 66.93 & 58.07 & 1647.5 & 0.076 \\
\hline Doping & 58.83 & 66.17 & 1694.5 & 0.103 \\
\hline Working in petrochemical industries & 60.70 & 64.30 & 1810.5 & 0.526 \\
\hline Prolonged standing & 62.81 & 62.19 & 1920.5 & 0.916 \\
\hline Contact with chlorine in swimming pools & 66.35 & 58.65 & 1683 & 0.167 \\
\hline Smoking & $67.66^{\mathrm{a}}$ & 75.34 & 1602 & 0.033 \\
\hline Alcohol drinking & 62.53 & 62.47 & 1920 & 0.991 \\
\hline Heavy activities & 58.04 & 66,96 & 1645.5 & 0.133 \\
\hline Cosmetic products & 58.52 & 66.48 & 1675 & 0.186 \\
\hline Wearing tight clothes & 60.44 & 64.56 & 1794.5 & 0.494 \\
\hline Excess chlorine in drinking water & 59.12 & 65.88 & 1712.5 & 0.245 \\
\hline Telecommunication towers & 66.58 & 58.42 & 1669 & 0.083 \\
\hline Excessive use of laptops & 67.81 & 57.19 & 1593 & 0.077 \\
\hline Pesticides & 64.20 & 59.89 & 1757 & 0.445 \\
\hline Preservatives & 66.5 & 58.5 & 1674 & 0.105 \\
\hline Medical drugs & 64.38 & 60.66 & 1808 & 0.229 \\
\hline
\end{tabular}

${ }^{\mathrm{a}}$ Statistically significant differences between males and females.

Table 3. Percentage of Infertility Risk Factors Known by Undergraduate and Graduate Males and Females ${ }^{\mathrm{a}}$

\begin{tabular}{lccc}
\hline Parameter & Males & Females & $\begin{array}{c}\text { Average Awareness of Males } \\
\text { and Females }\end{array}$ \\
\hline Undergraduate & 55.14 & 56.42 & 55.78 \\
Graduate & 49.40 & 62.5 & 55.95 \\
Average awareness & 52.27 & 59.46 & 55.86 \\
\hline a & & &
\end{tabular}

${ }^{\mathrm{a}}$ Values are expressed as \%.

course in the curriculum related to reproduction and fertility; therefore, higher female knowledge about IRFs may be obtained by extra-university study and may be related to their concerns about fertility.

As shown in Table 3, the overall awareness of under- graduate and graduate students is similar, but Sumera et al. showed that people with higher education have better knowledge in comparison to those with less education (57). Consequently, higher education does not increase student awareness about infertility risk factors in Iran, and this is related to the lack of campus teaching about this important subject.

Therefore, our study demonstrates that college students have a moderate level of knowledge about IRFs, that there is a gap relating to these factors, and that unfortunately education cannot be expected to increase their awareness. Therefore, a broad-based approach is needed to improve college students' knowledge in this area. The results also show that it is beneficial to have a teaching module curriculum that specifically focuses on the topic of infertility risk factors and infertility prevention. However, in order to provide this proposed education, more quantita- 


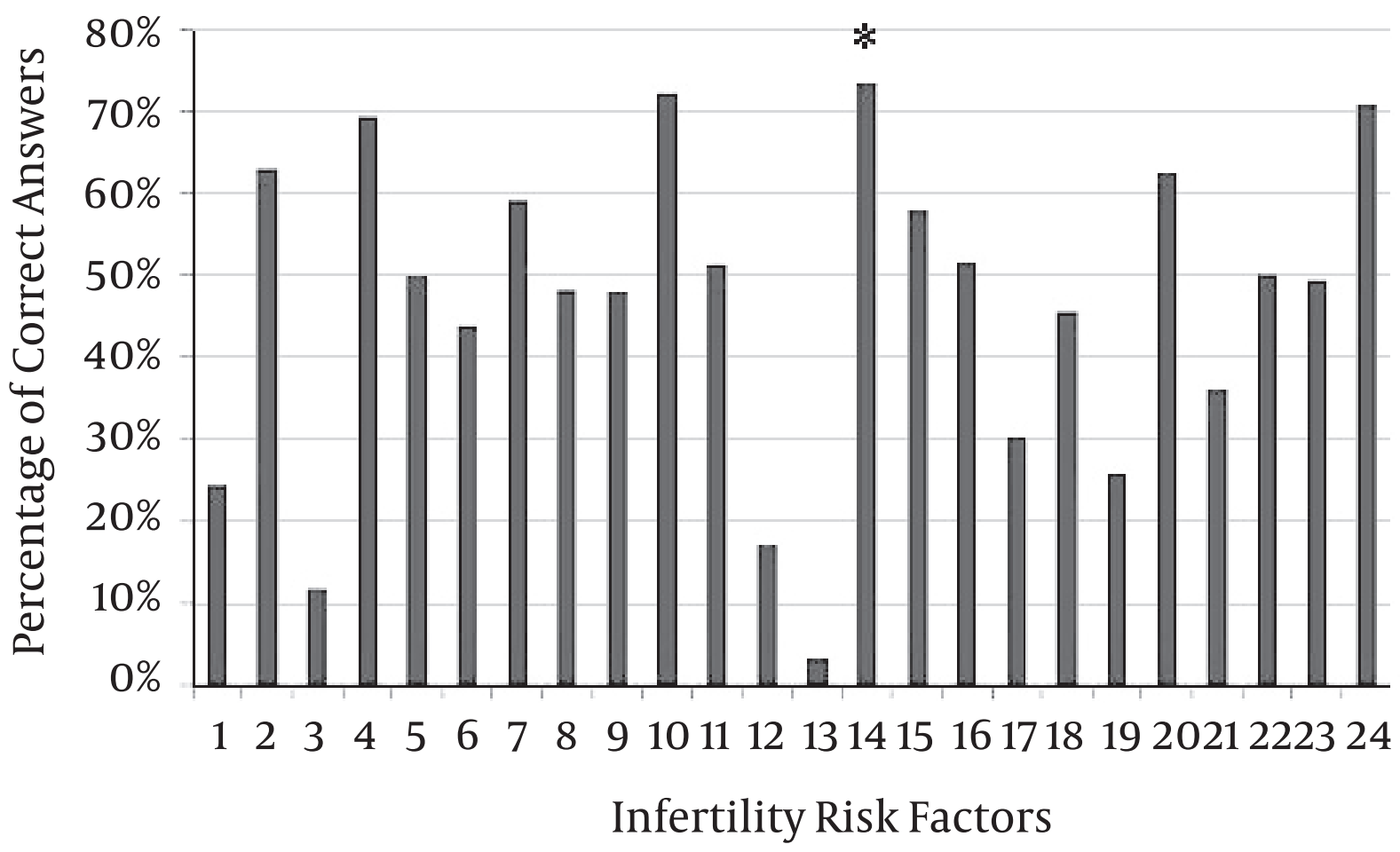

The most recognized infertility risk factor among these students was smoking (number 14 in Box 1).

tive statistical studies should be undertaken to determine the content of such a module. In addition to observations from campuses, the media can provide accessible information with the aim of promoting awareness in society about factors that influence fertility, so as to promote reproductive health and prevent infertility in our society.

Our study demonstrates that college students have a considerable knowledge gap relating to risk factors that affect fertility and that the awareness of females is more than that of males. Unfortunately, education cannot be expected to increase their awareness, but more accurate and detailed studies should be conducted in the future.

One of the limitations of the study is the generalizability of the results of this study. Our participants were from one university whose courses are all related to engineering, so our results cannot be representative of the views of other students from other universities and also the general population of Iran. Therefore, it would also be very beneficial to conduct a similar study in other universities and also perform comparisons among them to exactly determine college students' knowledge about IFRs.

Also, it is possible that, due to the nature of the questions being asked in the questionnaire, some students who were unsure of the answers were persuaded to choose the right answer rather than their actual choice, which is another limitation of this study.

\section{Acknowledgments}

The authors thank Fatemeh Mehrali, Secretary of the department of reproductive biology of Shiraz University Medical of Sciences, Shiraz, Iran, for her assistance. We also thank Jami institute of technology for providing an excellent platform for this study.

\section{References}

1. Alaee S, Talaiekhozani A, Rezaei S, Alaee K, Yousefian E. Cadmium and male infertility. J Infertil Reprod Biol. 2014;2:62-9.

2. Sinclair S. Male infertility: nutritional and environmental considerations. Altern Med Rev. 2000;5(1):28-38. [PubMed: 10696117].

3. Najafi TF, Roudsari RL, Namvar F, Ghanbarabadi VG, Talasaz ZH, Esmaeli M. Air Pollution and Quality of Sperm: A Meta-Analysis. IRCMJ. 2015;17(4).

4. Nieuwenhuijsen MJ, Basagana X, Dadvand P, Martinez D, Cirach M, Beelen R, et al. Air pollution and human fertility rates. Environ Int. 2014;70:9-14. doi:10.1016/j.envint.2014.05.005. [PubMed: 24879367]. 
5. Jurewicz J, Radwan M, Sobala W, Polanska K, Radwan P, Jakubowski L, et al. The relationship between exposure to air pollution and sperm disomy. Environ Mol Mutagen. 2015;56(1):50-9. doi: 10.1002/em.21883. [PubMed: 24989325].

6. Zeng Q, Wang Y, Xie S, Xu L, Chen Y, Li M, et al. Drinking-Water Disinfection By-products and Semen Quality: A Cross-Sectional Study in China. Enviro Health Pers. 2014 doi: 10.1289/ehp.1307067.

7. Ali A, Kurzawa-Zegota M, Najafzadeh M, Gopalan RC, Plewa MJ, Anderson D. Effect of drinking water disinfection by-products in human peripheral blood lymphocytes and sperm. Mutat Res. 2014;770:136-43. doi: 10.1016/j.mrfmmm.2014.08.003. [PubMed: 25771880].

8. Hamada AJ, Singh A, Agarwal A. Cell phones and their impact on male fertility: fact or fiction. The Open Reproductive Science. 2011;5(4):125-37.

9. Naziroglu M, Yuksel M, Kose SA, Ozkaya MO. Recent reports of WiFi and mobile phone-induced radiation on oxidative stress and reproductive signaling pathways in females and males. $J \mathrm{Membr}$ Biol. 2013;246(12):869-75. doi: 10.1007/s00232-013-9597-9. [PubMed: 24105626].

10. du Plessis SS, Kashou A, Vaamonde D, Agarwal A. Is There a Link between Exercise and Male Factor Infertility?. The Open Reproductive Science. 2011;3(1):105-13. doi: 10.2174/1874255601103010105.

11. Hirschberg AL. Women and sport. 2. sisusPort Books; 2014.

12. Koopman J. The Experimental Effects of Stress on Fertility. Berkeley Scientific. 2013;18(1).

13. Hansen PJ. Effects of heat stress on mammalian reproduction. Philos Trans R Soc Lond B Biol Sci. 2009;364(1534):3341-50. doi: 10.1098/rstb.2009.0131. [PubMed: 19833646].

14. Garolla A, Torino M, Sartini B, Cosci I, Patassini C, Carraro U, et al. Seminal and molecular evidence that sauna exposure affects human spermatogenesis. Hum Reprod. 2013;28(4):877-85. doi: 10.1093/humrep/det020. [PubMed: 23411620].

15. Carlsen E. History of febrile illness and variation in semen quality. Hu man Reproduction. 2003;18(10):2089-92. doi:10.1093/humrep/deg412.

16. McGill JJ, Agarwal A. The impact of cell phone, laptop computer, and microwave oven usage on male fertility. 2014 :161-77. doi:10.1007/9781-4939-1040-3 11.

17. Durairajanayagam D, Agarwal A, Ong C. Causes, effects and molecular mechanisms of testicular heat stress. Reprod Biomed Online. 2015;30(1):14-27. doi:10.1016/j.rbmo.2014.09.018. [PubMed: 25456164].

18. Pramanik P, Banerjee SB, Saha P. Primary dysmenorrhea in school going adolescent Girls-is it related to deficiency of antioxidant in diet? Int J Life Sci Phar Res. 2015;5:54-63.

19. Kumar V. Review of the factors influencing male infertility: An experimental study of effect of amalkirasayan and amalkiswaras with help of electron microscopy. $2014 ; 8(5,6): 28$.

20. Ilacqua A, Francomano D, Aversa A. Obesity and Testicular Function. 2015 :99-106. doi: 10.1007/978-3-319-09045-0_10.

21. Stokes VJ, Anderson RA, George JT. How does obesity affect fertility in men - and what are the treatment options?. Clin Endocrinol. 2015;82(5):633-8. doi: 10.1111/cen.12591. [PubMed: 25138694].

22. Binder NK, Sheedy JR, Hannan NJ, Gardner DK. Male obesity is associated with changed spermatozoa Cox4i1 mRNA level and altered seminal vesicle fluid composition in a mouse model. Molecular Human Reproduction. 2015;21(5):424-34. doi:10.1093/molehr/gav010.

23. Omu AE. Sperm parameters: paradigmatic index of good health and longevity. Med Princ Pract. 2013;22 Suppl 1:30-42. doi: 10.1159/000354208. [PubMed: 24051979].

24. Turchi P. Clinical Management of Male Infertility. Springer; 2015. pp. 5-11.Prevalence, Definition, and Classification of Infertility.

25. Naderpoor N, Shorakae S, de Courten B, Misso ML, Moran LJ, Teede HJ. Metformin and lifestyle modification in polycystic ovary syndrome: systematic review and meta-analysis. Hum Reprod Update. 2015;21(5):560-74. doi: 10.1093/humupd/dmv025. [PubMed: 26060208].

26. Gormack AA, Peek JC, Derraik JG, Gluckman PD, Young NL, Cutfield WS. Many women undergoing fertility treatment make poor lifestyle choices that may affect treatment outcome. Hum Reprod. 2015;30(7):1617-24. doi: 10.1093/humrep/dev094. [PubMed: 25924654].

27. Lynch CD, Sundaram R, Maisog JM, Sweeney AM, Buck Louis GM Preconception stress increases the risk of infertility: results from a couple-based prospective cohort study-the LIFE study. Hum Reprod. 2014;29(5):1067-75. doi: 10.1093/humrep/deu032. [PubMed: 24664130].

28. Kalantaridou SN, Zoumakis E, Makrigiannakis A, Lavasidis LG, Vrekoussis T, Chrousos GP. Corticotropin-releasing hormone, stress and human reproduction: an update. J Reprod Immunol. 2010;85(1):33-9. doi: 10.1016/j.jri.2010.02.005. [PubMed: 20412987].

29. de Jong AM, Menkveld R, Lens JW, Nienhuis SE, Rhemrev JP. Effect of alcohol intake and cigarette smoking on sperm parameters and pregnancy. Andrologia. 2014;46(2):112-7. doi: 10.1111/and.12054. [PubMed: 23230969].

30. Del Mar Mendoza-Lopez M, Reyes-Martin KI, Gutierrez-Gómez YY. Dietary Intake and Infertility: A Review. The FASEB Journal. 2015;29(1 Sup plement):590.12

31. Verze P, Margreiter M, Esposito K, Montorsi P, Mulhall J. The Link Between Cigarette Smoking and Erectile Dysfunction: A Systematic Review. European Urology Focus. 2015;1(1):39-46. doi: 10.1016/j.euf.2015.01.003.

32. Cao S, Gan Y, Dong X, Liu J, Lu Z. Association of quantity and duration of smoking with erectile dysfunction: a dose-response metaanalysis.J Sex Med. 2014;11(10):2376-84. doi:10.1111/jsm.12641.[PubMed: 25052869].

33. Lingappa HA, Govindashetty AM, Puttaveerachary AK, Manchaiah S, Krishnamurthy A, Bashir S, et al. Evaluation of Effect of Cigarette Smoking on Vital Seminal Parameters which Influence Fertility. J Clin Diagn Res. 2015;9(7):EC13-5. doi: 10.7860/JCDR/2015/13295.6227. [PubMed: 26393133].

34. Nieschlag E, Vorona E. MECHANISMS IN ENDOCRINOLOGY: Medical consequences of doping with anabolic androgenic steroids: effects on reproductive functions. Eur J Endocrinol. 2015;173(2):R47-58. doi: 10.1530/EJE-15-0080. [PubMed: 25805894].

35. de Souza GL, Hallak J. Anabolic steroids and male infertility: a comprehensive review. BJU Int. 2011;108(11):1860-5. doi: 10.1111/j.1464410X.2011.10131.x. [PubMed: 21682835].

36. Knuth UA, Maniera H, Nieschlag E. Anabolic steroids and semen parameters in bodybuilders. European Journal of Endocrinology. 1989;120(3 Suppl):S121-2. doi: 10.1530/acta.0.120S121.

37. Stojanovic MD, Ostojic SM. Limits of anabolic steroids application in sport and exercise. INTECH Open Access Publisher; 2012.

38. Karbalay-Doust S, Noorafshan A. Stereological estimation of ovarian oocyte volume, surface area and number: application on mice treated with nandrolone decanoate. Folia Histochem Cytobiol. 2012;50(2):2759. [PubMed: 22763965]

39. Skelton KV, Dowsett KF, McMeniman NP. Ovarian activity in fillies treated with anabolic steroids prior to the onset of puberty. J Reprod Fertil Suppl. 1991;44:351-6. [PubMed: 1795278].

40. Adams JA, Galloway TS, Mondal D, Esteves SC, Mathews F. Effect of mobile telephones on sperm quality: a systematic review and metaanalysis. Environ Int. 2014;70:106-12. doi: 10.1016/j.envint.2014.04.015. [PubMed: 24927498].

41. La Vignera S, Condorelli RA, Vicari E, D'Agata R, Calogero AE. Effects of the exposure to mobile phones on male reproduction: a review of the literature. J Androl. 2012;33(3):350-6. doi: 10.2164/jandrol.111.014373. [PubMed: 21799142].

42. Cummings DR. Additional confirmation for the effect of environmental light intensity on the seasonality of human conceptions. J Biosoc Sci. 2007;39(3):383-96. doi: 10.1017/S0021932006001568. [PubMed: 16911810].

43. Pall ML. Microwave electromagnetic fields act by activating voltagegated calcium channels: why the current international safety stan- 
dards do not predict biological hazard. Recent Res Devel Cell Biol. 2014;7.

44. Figa-Talamanca I. Occupational risk factors and reproductive health of women. Occup Med (Lond). 2006;56(8):521-31. doi: 10.1093/occmed/kql114. [PubMed: 17151388].

45. DeMatteo R, Keith MM, Brophy JT, Wordsworth A, Watterson AE, Beck $\mathrm{M}$, et al. Chemical exposures of women workers in the plastics industry with particular reference to breast cancer and reproductive hazards. New Solut. 2012;22(4):427-48. doi: 10.2190/NS.22.4.d. [PubMed: 23207955]

46. Nickmilder M, Bernard A. Associations between testicular hormones at adolescence and attendance at chlorinated swimming pools during childhood. Int J Androl. 2011;34(5 Pt 2):e446-58. doi: 10.1111/j.13652605.2011.01174.x. [PubMed: 21631527].

47. Nourmoradi H, Foroghi M, Farhadkhani M, Vahid Dastjerdi M. Assessment of Lead and Cadmium Levels in Frequently Used Cosmetic Products in Iran. J Environ Public Health. 2013;2013:1-5. doi $10.1155 / 2013 / 962727$.

48. Sharma R, Biedenharn KR, Fedor JM, Agarwal A. Lifestyle factors and reproductive health: taking control of your fertility. Reprod Biol Endocrinol. 2013;11:66. doi: 10.1186/1477-7827-11-66. [PubMed: 23870423].

49. Chiu YH, Afeiche MC, Gaskins AJ, Williams PL, Petrozza JC, Tanrikut C, et al. Fruit and vegetable intake and their pesticide residues in relation to semen quality among men from a fertility clinic. Human Reproduction. 2015;30(6):1342-51. doi: 10.1093/humrep/dev064.

50. Crinnion WJ. Toxic effects of the easily avoidable phthalates and parabens. Alternative Medicine Review. 2010;15(3):190-7.

51. Best Start Resource Centre. Workplace reproductive health, research and strategies,. 2001.

52. Lampic C, Svanberg AS, Karlstrom P, Tyden T. Fertility awareness, intentions concerning childbearing, and attitudes towards parenthood among female and male academics. Hum Reprod. 2006;21(2):558-64. doi: 10.1093/humrep/dei367. [PubMed: 16293651].

53. Peterson BD, Pirritano M, Tucker L, Lampic C. Fertility awareness and parenting attitudes among American male and female undergraduate university students. Hum Reprod. 2012;27(5):1375-82. doi: 10.1093/humrep/des011. [PubMed: 22407698].

54. Bunting L, Boivin J. Knowledge about infertility risk factors, fertility myths and illusory benefits of healthy habits in young people. Hum Reprod. 2008;23(8):1858-64. doi: 10.1093/humrep/den168. [PubMed: 18469334].

55. Quach S, Librach C. Infertility knowledge and attitudes in urban high school students. Fertil Steril. 2008;90(6):2099-106. doi: 10.1016/j.fertnstert.2007.10.024. [PubMed: 18321500].

56. Rouchou B. Infertility Knowledge, Attitudes, and Beliefs of College Students in Grenada. Science Journal of Public Health. 2015;3(3):353. doi: 10.11648/j.sjph.20150303.18.

57. Sumera AS, Sophie R, Imam FI, Khan FI, Ali SF, Shaikh A. Knowledge, perceptions and myths regarding infertility among selected adult population in Pakistan: a cross-sectional study. BMC Public Health. 2011;11:760. doi: 10.1186/1471-2458-11-760. [PubMed: 21970548].

58. Hammarberg K, Setter T, Norman RJ, Holden CA, Michelmore J, Johnson L. Knowledge about factors that influence fertility among Australians of reproductive age: a population-based survey. Fertil Steril. 2013;99(2):502-7. doi: 10.1016/j.fertnstert.2012.10.031. [PubMed: 23158832] 